\title{
Keeping up with the English Language in India
}

\author{
M. Shanmugathai, K. Poornima Varalakshmi
}

\begin{abstract}
Almost since the times of pre independence, the Indianness in English had started spreading diversified impact and unlimited changes deeply mingled with its cultural heritage which can be noticed predominantly in people belonging to all strata of society. Today, hybrid pattern of English stalks the land of India and helps to improve further more the popularity of already popular English. Indian English has a long journey and it has been steadily entertaining and educating by weaving and mixing innovative word power which goes strongly with the new age users who are familiar with multiculturalism, The reasons being technology, social media, the willingness to be techno-savvy and the touring populace. This paper throws light upon different aspects which ensure the fact that Indian English is here to stay for centuries ahead.
\end{abstract}

Keywords: Indian English, Diversified impact, Hybrid pattern, Multiculturalism, Technosavvy

\section{INTRODUCTION}

The Himalayan presence of English in India in the present century augurs well for unlimited foreseen \& unforeseen changes that will happen in the near future. India's dalliance with English began when the East India Company arrived in India in 1608. Of course, it has become a marriage of two incompatible partners through the centuries of the Raj. But the fascination for English gathered extraordinary momentum after the British left the country. The growth of the language in India over the years is so steady. From the 18th century onwards, when it came to an important communication, it has to be in English. This has been happening due to two reasons one is the changes and trends in journalism and another is the job of advertising.

The search for a 'higher' language continues throughout the history of the Indian encounter with English starting with early 18th century and going on through various stages of education, administrative reforms and then reaching up to the elusive search for an elitist social status. To-day trying to forge a connection with English is an effort that can be seen at every level.

It is very difficult to answer the question like this: who are the primary users of English in major countries of today? The most natural and immediate response would be that these are upper class people, who belong to the leading strata of a society. It is true that in most of these countries, English Language has been taught from the preschool level. Often there is a strong feeling is in existence that if a student is good in language, particularly in a foreign tongue like English, the quality of his performance in different endeavours related to his studies seems to be good. Edgar W. Schneider (2011) says that there is an enormous liking / preference for English to

Revised Version Manuscript Received on 10 September, 2019.

M. Shanmugathai, Professor in English, Sri Sai Ram Engineering College, Chennai-44,Tamilnadu, India.

K. Poornima Varalakshmi, Assistant Professor in English, Sri Sai Ram Institute of Technology, Chennai-44,Tamilnadu, India. learn all subjects related to one's education, precisely out of the instrumental motivation, because knowing better English always assures asserted status in society and lucrative job opportunities as well. So even the not so highly qualified individuals tend to practice English language skills for spontaneous communication not only to come up in life financially but also to attain different posts/positions by excelling in trade, tourism and politics.

As said earlier, when attempts are made to flourish in the usage of English, it is clearly observed that an amazing variety of semi fluent usage is noticed. Viniti Vaish (2008) describes the acquisition and use of English language in a lower middle class Government School in New Delhi, and she comments of English though members of it can listen, read and write. It is not the class that speaks Indian English. But this group handles the English language for personal objectives, similar skills like obtaining a license for driving a car to be a good earning driver.

An educated \& techno-savvy youth, today, may find it difficult to understand the meaning of the sentence: the manager is a man of letters. In its true sense, the meaning is that the manager has sound English writing skills. But the perceived meaning is that the manager has the habit of producing letters for too many occasions. A great many Indian writers took the letter form to exhibit their writing skills. The first Indian book in English was epistolary, written by Dean Mohamed (1759-1851) who wrote letters about his travels and life. In the year 1934, Peter Davies Ltd published "Letters of an Indian Judge to an English Gentlewoman". The Judge Arvind Nehra was an Anglophile, and most of his letters were cloyingly sentimental about everything British. Further Nehru's letters though had no clear instances of Indian usages, it served to show Indian fascination for the epistolary form especially when it came to writing in English. Binoo K. John (2007) says that the Indian fascination for the writing of letters - good, bad, literary and indifferent - in English has had a wide ranging fall-out: the growth of Indian -English. Not everyone had the literary or descriptive powers of Nehru or Dean or other early Indian letter writers. Their ambitions were confined to seeing their letters printed in newspapers and suffixed with their pen names, as one can see.

Binoo K. John continues saying that Indianised English language will survive by all means defying all logic. Even the 'colour' will be changed due to different groups belonging to different states of India who use the language with their own flavour. A Keralite's English is different to a person from West Bengal and similarly different to that of a Mumbaikar, who of course proves that he is from the trade capital of the 
country. A Tamilian will claim that his use of the language is similar to that of a native speaker than the language of the people from different parts of the North India. From Tagore \& Nehru to Anitha Desai \& Chetan Bhagat no one has missed the much researched Indianness in English. So language is a powerful tool to touch the sentiments of the public. This is the age where the world is ruled by democratic tongues of the common men. If one wants to reach the people, one should speak their language.

People believe that a language is a very simple thing, if only because every healthy human being speaks one, and thus we believe that we know everything that needs to be known. Language varieties are unlimited. They include standard language and unlimited varieties and multiple dialects which are created due to regional differences, social differences and educational differences. Compounds like Lady doctor, Rickshaw wallah and speeches like pelt something at someone (rather than pelt someone with something) and you are coming know? (rather than Are you coming?) are very common. Indian English changes all the time, whether one prefer its or not, and irrespective of whether one is aware of this or not. Lexical innovations, fashionable words, idioms \& phrases from sports write-ups, adjectives \& adverbs from advertisements and internet terminology have brought numerous changes as well. Irrespective innumerable changes the educated strata of India have the belief that English language unites all Indians.

\section{RESULTS \& DISCUSSIONS}

It is true that Post - Independence India tried to do away with the fondness for the foreign tongue. Unfortunately that simply never happened. But numerous attempts simply did not work out. Then the idea of having the "Three - Language Formula" from the Language Act of 1967 was recommended for making the Hindi language the broadly spoken language for the nation and at the same time not to affect the state languages until the time English could be identified as easily dispensable. But no one is willing to accept the uniformity in adhering to one language process. Be it from northern boarders or from the southern states people, everyone was reluctant to accept the others' languages and consequently the indispensable nature of English was proved and then English originated in Indian soil. Obviously, a distinctive Indian English has evolved with some regional pronunciation differences and has become one of the world's main varieties, based on speaker numbers. Uses of English or Indian English are clearly associated with elite strata of society, stigma for high quality education and a solid weapon to fine tune or doing it 'big' in educational arena, political scenario or any other top notch field. But, this sociolinguistic restriction, while being reasonably typical and true, has never been the whole story, and increasingly less so in recent times with all their mobility and many social changes.

Edgar. W. Schneider (2011) affirms that even in earlier times amongst the soldier and staff stationed in India, there were many lower-class and middle-class dialect speakers who were in touch with common Indians who have shown tremendous liking to articulate in English. Reportedly, a big, sizable Indian community, settled in Britain for long so called "White Babus", had followed widely preferred, highly fashioned English. In the recent past, the association with
English and accessibility to get lucrative job offers and ensuring richness / money making turned out to be the valid reasons for readily adopting the English language. Previously, life was led only with the Indian native tongues and a sea change was noticed slowly and steadily.

The Pro-English debate was so passionate in Tamil Nadu (South of India), where this demand resulted in anti-Hindi agitation. Better to use English than Hindi, was the cry of the Tamilians, and that had vast impact in other southern states as well. The deviation between north and south ensures that there are plenty of Indianised forms of English used confidently, lavishly and extensively in hoardings, advertisements, letters and literary genres and which has made already Indian - English into an accepted form. Though there has been a tussle between India (state wise separately too) and English always, most of the time the result ends in favour of English only. 'The lure of English' has predominant presence. This can be felt by observing the following advertisement. "How to get English to roll off your tongue!", "How to master English", "Learn English \& Earn Better", "Speak spontaneously \& stylishly", "Our tongue, their Tongue". There are plenty of advertisements for English conversation coaching happening in the land of more than 20 solid languages and the land of huge population.

English is creditably ruling the Globe as the lingua franca and the journey of the language had been steady, but the point of origin is not smooth too. An acclaimed French businessman Nerriere (1995) formulated the term "Globish" for its far \& fast reaching abilities. The history of English language proves that only the beginning was tough. To pass on the communication with effortless ease, undoubtedly, English has attained an unassailable lead amidst many languages in the globe.

International Sports, Advertisements, Music Albums, Innovations and Fashion Explorations bring the language certainly and constantly forward. Every year, contests like the Best Tagline for a product, the Best Advertisement film (usually in a maximum of 3 minutes) and the Best Translation work easily help to bring plenty of factors related to Indianism.

English as a Lingua Franca (ELF) connects people especially international students. The purpose does not end with that. The worldwide internet users and regional wise users, here, Indians prefer to use separate words for immediate application, negotiation and communication processes. In other words, Indian internet users for communication with foreigners prefer to avoid locally flavored English words. But, English in India used by Indians takes a different colour. A vastly populated and culturally diversified country like India never will be satisfied with one uniting language that belongs to the native land. The borrowed English will survive but will be tested time and again by technological advancements, politics, business, media sports and cinema. 
Indian English will survive since Indians have accepted whole heartedly the English language and they know how to use words that work during all occasions. Everyone knows that International English does not belong to any region of any part of the Globe. Being the major language for multipurpose \& multinational activities and affairs, there has been no "Textbook Pattern" for using the language. This idea provides/enables users to bring unlimited modifications and changes in the usage of phrases and pronunciations. So especially in India, the deviations are aplenty. Social media plays a pivotal role in providing short forms for words and emotions. Twitter, Facebook, Instagram ,Whatapp and Mobile texting attribute in a mind boggling way for bringing/introducing a new vocabulary, since the percentage of social media users is alarmingly large. Transcriptions and Translations are huge in number in India. The subtle use of words in English is no more the order of the age. The successful communication or conveying the information comes as the sole objective, no searching or researching is happening in a broader perspective.

\section{REFERENCES}

1. A Binoo K. John. Entry from Backside only - 2007 Penguin Books India.

2. Crystal, David. 1988. The English Language. London: Penguin Books.

3. Dr. Frank Luntz - Words that work - 2007 - Hyperion New York.

4. Edgar W. Schneider. English Around the world - 2011 Cambridge University Press.

5. Vaish, Viniti. 2008 - Biliteracy and Globalization: English Language Education in India. Clevedon: Multilingual Matters. 